\title{
LOS AÑOS DE LA CASA DE CARTÓN
}

\section{THE YEARS OF THE CARDBOARD HOUSE}

(Fragmentos de la novela)

\author{
Eduardo Arce Tello ${ }^{1}$ \\ Universidad Nacional Mayor de San Marcos, Lima, Perú \\ (RECIBIDO 10/11/2009, AcEPTADo 15/10/2009)
}

\section{BÚSQUEDA PUGNAZ}

Tengo que admitir que soy un inconforme. Tenía facilidad para escribir, la revisión me llevaba a construir, borrar y nuevamente elaborar. Sin embargo, pocas veces quedaba satisfecho. Es difícil transmitir lo que uno siente. Me sentía acosado por una búsqueda permanente. No se trataba de la tarea de agregar un nuevo adjetivo o llevar por un cauce inesperado a la narración. ¡De ninguna manera; Sólo en la búsqueda pugnaz hallaba satisfacción. No quedé contento hasta anotar que, me gustan los colores del cielo porque es seguro que no son tintes alemanes. Cuando escribía la simiente de inconformidad me acompañaba, me decía por dónde ir, por eso creo que siempre supe que miraría el paisaje local de manera universal.

Además de inconforme, suelo ser porfiado en las correcciones. Me gustaba subrayar los libros tratando de ir al fondo del sentido de las palabras, descubrir el encanto casi secreto de algunas frases como, "ictiologizado", nada se comparaba a este hallazgo, sentía una singular emoción al acercarme con sigilo al auténtico sentido de las palabras, ¿era ciencia mi búsqueda?, ¿existiría el trabajo de poeta?, ¿sería así la vocación del aprendiz de poeta? Mi madre me encontraba a veces dormido sobre los libros, yo apreciaba el cuidado que ella ponía para llevarme casi como a un sonámbulo, a descansar a mi cama donde quedaba rendido hasta la mañana siguiente.

No es que sea un maniático en los detalles, pero me gusta el orden. En mi escritorio guardo unos cuadernos de filo rojo. Allí se encuentran mis preciados tesoros, los originales de La Casa de Cartón. Cuando no los tengo a mano, emborrono unas libretas menudas de tapas negras y celestes, que suelo llevar en el bolsillo. Que sosiego me embarga cuando hallo la palabra que busco; siempre la elijo por su capacidad de sugerencia, quien sabe, de ruptura, contradicción y en ocasiones por su llamativa vistosidad.

1 El autor de la novela, el psicólogo Eduardo Arce Tello, quien cursó estudios y se tituló en la Facultad de Psicología de la UNMSM, en 1980, ha tenido la gentileza de alcanzarnos para su edición algunos fragmentos de la ficción histórica inédita que aborda la vida juvenil del poeta peruano Martín Adán (Rafael De la Fuente Benavides), período en que elaboró la novela poemática "La casa de cartón". Eduardo Arce refiere que la presente novela ha sido construida después de una exhaustiva revisión de las obras completas en prosa y verso, bibliografía y textos críticos sobre el autor; y anuncia su publicación en el presente año. 
Asumo que, llevado por mi interés, más que eso, por la pasión de hurgar en los orígenes y resonancias de las palabras, hizo que engullera cuanto libro cayera en mis manos; sin embargo, nunca sería ese lector que aprieta el culo en la silla, aquel calienta posaderas que tanto detesto. Mi método de estudio es semejante al peripatético; cuando indago sobre un tema, voy con mis notas de un lugar a otro. En mis bolsillos no cabían los menudos papeles, testigos de infatigables búsquedas de alguna manera relacionadas a la literatura, ya en casa, los depositaba en una gaveta. Pude darme cuenta que mi afán por la literatura fue cada vez más vigoroso, consumía el sueño de muchas noches, dormía poco, leía, leía y escribía hasta terminar agotado, era quizás la costumbre de trabajar hasta el límite; al día siguiente, despertaba con buen ánimo, mi cuerpo no se resentía con el esfuerzo desplegado. Más tarde caería en cuenta que, sin esta tenaz labor, mi vocación por las letras habría menguado. Entendería también que, algunos trabajan con el acero, la argamasa y en el socavón minero, unos pocos enfebrecidos, adarga y lanza en ristre, emprenderíamos, el difícil camino de la literatura.

\section{NACIMIENTO}

Esa tarde, en casa, pasamos unas horas agradables, conversando con mi madre, luego, en un aparte y con un tono intimista, que sólo empleaba para hablar de asuntos familiares, me contó algunas cosas referidas a mi nacimiento y a mi nombre. Dijo que si yo hubiera nacido el 18 de octubre sería Lucas; si es el 19 no habría remedio Lucio; si hubiera ocurrido el 20 el grave Juan o Cancio; si llegaba el 21 tendría el nombre de un hombre bueno como Hilarión; si caía a mitad de semana, el jueves 22, mi nombre de pila sería Marcos como el apóstol; si pasaba al viernes 23, Pascual; cosas del destino, quizás esperaría a un artista como Rafael si fuera el sábado 24; el domingo 25 estaría reservado a Crisanto, el lunes 26 a Evaristo, el martes 27 a Florencio y, en todo caso, si ocurriera el miércoles 28 tendría el nombre de Judas Tadeo, el santo del trabajo. ¡Qué difícil elegiri Tía Tarcila, nunca fue amiga de las supersticiones, pero una vez contó que doña Panchita, había comentado que la fecha de mi nacimiento acaecido a la una del día de aquel martes 27 de octubre de 1908, auguraba maravillas para los nacidos ese día, sobre todo en actividades relacionadas con el trato con las palabras y los escritos, todo indicaba que sería un abogado de mucho éxito.

Doña Panchita era una mujer gorda, muy sabia y de buen carácter, que vivía por La Raya de Bolivia; estaba relacionada con nuestra familia desde cuando ella siendo una jovencita había entrado a servir en casa de mis abuelos. Ayudaba en la cocina y algunas veces en el lavado y planchado de ropa; casi siempre que tía Tarcila tenía invitados, buscaba lucirse con algún platillo especial, que causaban admiración. Además, había ganado fama por todo el Barranco de ser entendida en temas de adivinar el futuro de las personas.

Ocho semanas después de aquella animada conversación con mi madre y cuando llegaba del colegio y entraba corriendo por el corredor, sentí que la mano de doña Panchita me tomaba del brazo llevándome hacia la cocina donde me sirvió un enorme tazón de arroz con leche que había preparado. Niño Rafael, dijo, le voy contar algo que es sabiduría de negros, no pregunte como sé, pero, le diré que veo en usted a un caballero que dedicará su vida a averiguar el porqué de muchos temas, que sus ideas serán nuevas, diferentes, 
que usará mucho la tutuma pensando asuntos bien difíciles que la gente no entenderá y creo que pasarán muchas lunas para que a las personas les entre en la cabeza. Usted será persona de muchos méritos, siempre le reconocerán lo que vale, niño.

Lo que sí me preocupa, niño Rafael, es que en todita su vida nunca estará conforme, - disculpe, usted - será un rebelde, hará lo que quiere, aún, cuando toditos estén en su contra. Usted prefiere la vida solitaria, pero eso le hará daño, no es bueno aislarse, la soledad llena la mente de cosas sin pies ni cabeza y se sufre, usted es un soñador y por ser así tendrá muchas desilusiones. Le pido permiso niño para decirle algo que me da mucho temor contarle, - continuó a mi pedido - es una visión terrible, usted está vestido con un enorme saco estropeado y sucio caminando por las calles, la gente volviéndose para decir ese es el doctor De la Fuente, usted fumando, caminando sin fijarse en nada, como si no le interesara lo que piensan los demás... iperdóneme niñoj Sólo espero que en su vida haiga mucha abundancia, que sea rico y poderoso, es mi deseo; le pido mil disculpas por gastar su tiempo oyendo a esta negra que lo quiere mucho niño Rafael; luego, dejó su delantal a un costado de la mesa y se alejó casi a la carrera; a la distancia me pareció escuchar unos sollozos ahogados, ¿esta extraña confesión la habría hecho llorar?

Con sinceridad, me quedé muy sorprendido y sin saber el por qué de esta conversación, que traté de olvidar, pero las palabras de Panchita expresadas con esa simpleza y ternura tan suya habían logrado perturbarme como si fueran los designios de una profecía.

$* * * * * * * * * * * * * * * * * * * * *$

\section{ESCALA MUSICAL DEL AGUA}

El domingo que visitamos a José María se hallaba en un estado especial. Con asombro le escuchamos mencionar de la escala musical del agua. Ante nuestra incredulidad, insistía, argumentando que, en alguna ocasión habíamos tenido noticia, del agua cantarina. En ese momento creía reconocer la presencia de la música en muchísimas cosas, por no decir en casi todo, nosotros no sabíamos si tomarlo en serio cuando se refirió a la flor del do y casi en vilo, nos hizo acompañarlo al jardín contiguo, el dueño de ese vergel, al verlo, muy amable, dijo, pase señor Eguren está en su casa. José María devolvió el saludo y con el índice derecho extendido, señaló a una azucena del jardín y nos dijo, esta es la flor del do, la más diáfana y bella, ¡deslumbra su blancura;, la sostuvo un buen rato y luego, inclinando la cabeza al igual que un violinista parecía seguir con el cuerpo una inaudible sinfonía, después se sumió en un largo silencio y así, acompañándolo en su mutismo regresamos a casa. No hicimos nada para concluir estas ausencias, tácitamente supusimos que las musas habían descendido y le acompañaban. Asumí que en ese momento, sí, en este instante de tiempo, el poeta sería quizás arrojado del paraíso o ingresaba a este.

Camino a casa, pensé que esa tarde, como en ninguna otra, había sido la del pulcro encuentro del poeta con las ninfas celestiales. 


\section{PODRÍA HALLARLO ENTRE LAS FLORES}

Cuando César y yo éramos niños y caímos enfermos de escarlatina, surgieron complicaciones que tuvieron que llevarnos de urgencia al hospital, para ser operados. Muchos días después de aquella intervención al oído de la que conservo aún una fea cicatriz, me acosaron ruidos infernales que atravesaban el interior de mi cerebro, sonidos que se espesaban, agostaban, silbidos interminables, chasqueantes, fffllliiii, ffffllllaaaa, chasss, pllliii, gggghhh, raassgg, que casi me volvían loco, el dolor no cesaba, felizmente la compañía de mi madre permitió que superara esos difíciles momentos.

Fueron días de fiebres altas, sopor y decaimiento. Amanecía con un sabor metálico en la boca y pesaban los párpados. Cuando regresé a casa y observé el rostro de mi madre creí comprender lo que había ocurrido. No tuvieron más remedio que contarme que mi único hermano había muerto, dijeron que César no pudo soportar la grave enfermedad, fueron días donde lloré incansablemente; recuerdo que nada me consolaba. Mucho más intenso fue el sentimiento de soledad, tocaba las paredes, sus juguetes, como si tratara de asir su presencia. Él está aquí, repetía, fijando la mirada en su fotografía donde lucía ropa de marino, con pantalón corto, gorra y se mostraba risueño. Casi no podía dormir, me acosaban pesadillas, soñaba con un mar inmenso poblado de casquetes de hielo que rompían las olas con furia, desmoronando grandes pedazos que caían en un voraz remolino de horror. Despertaba sobresaltado, con la respiración entrecortada, recordando vívidamente las imágenes del sueño, me molestaba escuchar el canto de una cuculí en la ventana. Nada me confortaba, sentía que el destino se había ensañado conmigo. Ya habían pasado los tiempos felices con su compañía: todo él chispa, gracia, buscándole el lado humorístico a las cosas.

En esos días, mi casa se encontraba iluminada por unos candelabros que irradiaban una luz amarilla. Asociado a ese detalle quedaron impregnadas en mi memoria la muerte de mi hermano. Me invadió un extraño miedo, odiaba a las personas, prefería estar solo. Fui preso de angustia cuando imaginaba que correría igual suerte que él; donde fueron un bálsamo los poemas Cantos a mí mismo de Whitman, particularmente, aquellos versos que decían: no desapareceré como el círculo de fuego que traza un niño en la noche con un carbón encendido. Esos versos me dieron fuerza de ánimo.

Luego de la convalecencia cuando pude nuevamente salir a caminar, iba por el sendero que antes recorría con César y creía verlo emerger de entre las hierbas dando brincos rápidos desaparecía y perdía su rastro entre las sombras rojizas del crepúsculo. Me quedaba con la sensación remota de que quizás podría hallarlo entre las flores, en los granos de tierra que por ahí escaparon de sus manos, al pie del grueso ficus que trepaba para contemplar como el viento dibujaba caprichosas formas con las nubes. Me parecía que escuchaba su voz repitiendo en el eco de la memoria, ¡mira unos castillos, allí un caballo, ese tambor gracioso!, son tantos recuerdos, creo que si no hubiera estado mi madre, tal vez enloquecería.

Con el tiempo y la resignación todo fue volviendo a la normalidad. Era agradable volver a escuchar el trácata trácata del tranvía; la inocente caída del agua en el interior de casa y el lejano rumor del mar. Me acostumbré a la inevitable sordera de un oído, superada esa incomodidad, los indiferentes sonidos de la naturaleza, fueron como un universo abierto 
que apenas había atisbado. Descubrí que esa limitación rompió mis adormecidos sentidos. Aunque era una tremenda exageración, no encuentro palabras, podía sudar colores y olfatear sonidos.

Nunca dejé de extrañar a César. Recordaba los momentos felices que pasamos en familia. Se encontraba fresca en mi memoria las escenas que representó después que salimos de la misa dominical. César hacia gestos que imitaban los ademanes del sacerdote en el púlpito. Mi madre iba distraída. Él se contorsionaba y esgrimía frases novedosas en latín, desacostumbradas para su edad. Empecé a reír y todos se contagiaron de mi risa.

Ese suceso, como otros donde mi pequeño hermano mostraba su vena irónica además de provocarme risa, hicieron que pensara, que muchas cosas podían ser vistas con otros ojos y viéndolas así como que se iluminaban; quizá por eso reparé en que, la percepción ingenua de las cosas era una estúpida camisa de fuerza, casi como aquel murmullo: verdad tontitos, el techo se viene abajo, así, el techo se viene abajo. ¡Qué curioso, no era nada fácil, había que aprender a mirari

¿Necesitaría cierto entrenamiento aprender a mirar las cosas que nos rodean?, ¿y, cómo sería el ideal? Quizás una mirada desbastadora que se concentre en lo sustancial y aquello lo transmita en un lenguaje inocente; sí, inocente, por el grito de recién nacido, único en el universo. 